\title{
Hukum administrasi perubahan penggunaan lahan untuk pengembangan perumahan
}

\author{
Rosail Akhyari Pardomuan ${ }^{\left.1^{*}\right)}$, Afriva Khaidir ${ }^{2}$ \\ ${ }^{12}$ Universitas Negeri Padang
}

\begin{tabular}{l} 
Article Info \\
\hline Article history: \\
Received Jan $30^{\text {th }}, 2021$ \\
Revised Feb $09^{\text {th }}, 2021$ \\
Accepted Feb $16^{\text {th }}, 2021$
\end{tabular}

\section{Keyword:}

Administrative law Environmental Housing development Land use change Sustainability

\begin{abstract}
ABSTRAK
Tujuan penelitian ini adalah untuk menganalisis hukum administrasi di Kota Padang terhadap perubahan penggunaan lahan untuk pengembangan perumahan. Selama tidak adanya kesepakatan antar anggota kaum, maka tidak diperbolehkan transaksi tanah untuk pengembangan perumahan. Hal ini didasarkan atas sistem kemasyarakatan yang berpolakan matrilineal (garis keturunan ibu) yaitu dari mamak kepada kemenakan. Namun, keadaan ekonomi masyarakat sangat berpengaruh terhadap keputusan masyarakat untuk menjual lahannya. Transaksi ini baru dibolehkan setelah melalui rapat kaum yang dipimpin oleh penghulu dengan didasarkan atas beberapa pertimbangan, seperti "rumah gadang katirisan, gadih gadang indak balaki, mayik tabujua ditangah rumah, mambangkik batang tarandam". Selanjutnya, penyalagunaan lahan untuk pengembangan perumahan akan berdampak pada hilangnya area resapan air hujan yang menyebabkan rusaknya kelestarian lingkungan, terganggunya keseimbangan ekologis, tercemarnya air, dan banjir. Setiap hujan dengan intesitas sedang hingga deras beberapa kawasan permukiman di Kota Padang mengalami banjir, sejumlah kawasan seperti Siteba, Alai, Mata Aia, Jondul Rawang, Sungai Sapih dan lainnya.
\end{abstract}

(C) 2021 The Authors. Published by IICET

This is an open access article under the CC BY-NC-SA license

(https://creativecommons.org/licenses/by-nc-sa/4.0)

\section{Corresponding Author:}

Rosail Akhyari Pardomuan

Universitas Negeri Padang

Email: rosail.akhyari@gmail.com

\section{Pendahuluan}

Kota Padang adalah kota terbesar di pantai barat Pulau Sumatera sekaligus ibukota dari Provinsi Sumatera Barat. Kota Padang mengalami laju pertumbuhan penduduk rata-rata per tahun dalam rentang Tahun 2010 sampai dengan Tahun 2019 adalah sebesar 1,47\% (Badan Pusat Statistik, 2020). Jumlah penduduk Kota Padang pada Tahun 2010 adalah sebanyak 833.562 jiwa. Pada Tahun 2015 sebanyak 902.413 jiwa. Dalam lima tahun itu bertambah sebanyak 68.851 jiwa. Pada Tahun 2019 jumlahnya menjadi sebanyak 950.871 jiwa (Badan Pusat Statistik, 2020). Kondisi ini menyebabkan penggunaan lahan tidak sesuai kemampuan lahan, daya dukung lahan, dan peruntukannya, sehingga terjadi perubahan penggunaan lahan. Perubahan tersebut ditandai dengan berdirinya bangunan-bangunan dengan fungsi sebagai hunian, industri maupun perdagangan dan jasa, penggunaan lahan di suatu wilayah selalu terkait dengan pertumbuhan penduduk dan aktivitasnya (Wahyu, Haryani, \& Nori, 2020). Semakin meningkatnya jumlah penduduk dan intensifnya aktivitas penduduk di suatu tempat berdampak pada makin meningkatnya perubahan penggunaan lahan. Pertumbuhan dan aktivitas penduduk yang tinggi terutama terjadi di daerah perkotaan, sehingga daerah perkotaan pada umumnya mengalami perubahan penggunaan lahan yang cepat (Wahyu et al., 2020). Selain itu, kepadatan penduduk, pertambahan penduduk, perkembangan ekonomi akibat urbanisasi yaitu perluasan penduduk kota 
ke pinggiran kota, tidak diimbangi ketersediaan ruang yang digunakan untuk pemenuhan kebutuhan perumahan, perkantoran, perindustrian, sehingga menyebabkan perubahan penggunaan lahan bagi daerahdaerah hijau dan terganggunya kualitas lingkungan (Bintarto, 1984).

Kondisi ini menyebabkan konflik lahan muncul dari berbagai faktor yang saling terkait seperti tekanan populasi yang tinggi, komersialisasi lahan, implementasi kebijakan neoliberal, formalisasi hak atas tanah, dan perampasan lahan oleh investor domestik dan asing (Agheyisi, 2019; Berry, 2009; Boone, 2017; Kuusaana, Bukari, Danyi, \& Bukari, 2015; Mwesigye \& Matsumoto, 2016). Faktor-faktor yang saling berhubungan ini memicu kelangkaan tanah yang menyebabkan perselisihan atas tanah antara otoritas tradisional dan anggota masyarakat (Kalabamu, 2019). Di Kota Padang munculnya konflik tanah karena adanya pandangan bahwa pembagian harta warisan tidak adil, ini disebabkan karena kekaburan garis keturunan keluarga, sehingga antara jurai yang satu dengan jurai yang lainnya saling mengklaim harta pusaka (Akbar, 2010). Sementara di Afrika Sub-Sahara, konflik lahan biasanya terjadi antara keluarga, kelompok etnis, petani dan pendatang (Knox \& Jones-Casey, 2011). Konflik tanah lokal sangat merajalela di masyarakat dengan beragam kelompok etnis dan pendatang (Kalabamu, 2019). Di Botswana konflik tanah lokal terjadi sebagai akibat dari penerapan kebijakan neoliberal dan bangkitnya kelas elit.

Masalah tanah di Minangkabau berarti membicarakan pula masalah hukum adat Minangkabau. Hal ini disebabkan karena masalah tanah adalah bagian yang tidak terpisahkan dari hukum adat Minangkabau itu sendiri (Anwar, 1997). Tanah di Minangkabau merupakan suatu identitas diri karena tanah disini berfungsi sebagai pengikat hubungan baik antara suku maupun kaum sekaligus sebagai bukti asal usul. Sejalan dengan di Kota Ghana, meningkatnya permintaan akan tanah adat untuk pembangunan perumahan yang muncul dari urbanisasi yang cepat memungkinkan semua kelompok sosial seperti penguasa adat, kepala marga dan anggota masyarakat untuk mengalokasikan tanah kepada pembeli tanah (Fosu, 2021). Penjualan tanah pusaka di Minangkabau baru dibolehkan setelah melalui rapat kaum yang dipimpin oleh penghulu dengan didasarkan atas beberapa pertimbangan, seperti "rumah gadang katirisan, gadih gadang indak balaki, mayik tabujua ditangah rumah, mambangkik batang tarandam" (Anwar, 1997). Tujuan penelitian ini adalah untuk menganalisis hukum administrasi perubahan penggunaan lahan untuk pengembangan perumahan.

\section{Metode}

Jenis penelitian ini adalah penelitian kepustakaan, yaitu serangkaian penelitian yang berkaitan dengan metode pengumpulan data perpustakaan, atau penelitian yang objek penelitiannya dieksplorasi melalui berbagai informasi perpustakaan (buku atau jurnal ilmiah) yang membahas tentang hukum administrasi perubahan penggunaan lahan untuk pengembangan perumahan. Penelitian perpustakaan atau tinjauan pustaka adalah studi yang secara kritis memeriksa pengetahuan, ide, atau temuan yang terkandung dalam tubuh literatur berorientasi akademik (Syaodih, 2009).

\section{Hasil dan Pembahasan}

\section{Penyebab perubahan penggunaan lahan untuk pengembangan perumahan}

Perubahan penggunaan lahan untuk pengembangan perumahan disebabkan oleh tingginya permintaan akan lahan pinggiran kota untuk pembangunan perumahan, karena harga tanah di pusat kota yang lebih tinggi dari harga tanah di pinggiran kota (Kleemann et al., 2017). Harga tanah perkotaan yang tinggi terjadi sebagai akibat dari pertumbuhan perkotaan yang semakin meningkat yang berasal dari peningkatan alami, migrasi internal yang tidak terkendali dan globalisasi (Barry \& Danso, 2014; Kleemann et al., 2017; Siiba, Adams, \& Cobbinah, 2018).

Selain itu, keadaan ekonomi masyarakat sangat berpengaruh terhadap keputusan masyarakat untuk menjual lahannya, penghasilan dari pertanian tidak lagi mampu memenuhi kebutuhan, ada kemungkinan lahan akan dijual dan beralih profesi ke kegiatan non pertanian (Jauhari \& Ritohardoyo, 2013). Namun bagi pemilik lahan yang tetap bertahan dengan kegiatan pertanian, terdapat dua kemungkinan. Pertama, pemilik lahan tetap mempertahankan lahan yang dimiliki dan tidak menjual lahannya. Kedua, pemilik lahan menjual lahan dengan harga tinggi untuk membeli lahan yang lebih murah (Jauhari \& Ritohardoyo, 2013). Selaras dengan, rendahnya pendapatan usaha petani, dan kecenderungan pemilik lahan untuk bekerja di sektor bukan pertanian (Dewi \& Rudiarto, 2013). Misalnya: lahan sawah memiliki masalah karena produktivitas yang mendekati levelling off dan nilai land rent yang tinggi, sehingga lahan sawah sangat rentan terhadap alih fungsi lahan (Sitorus, 2018). Area dekat pusat kota dan area pintu masuk kota pada umumnya menjadi tempat alih fungsi lahan pertanian (Dewi \& Rudiarto, 2013). Sama halnya dengan di Ghana, tingginya permintaan lahan untuk pembangunan perumahan menyebabkan otoritas adat menggusur petani dari lahan pertaniannya 
dan mengalokasikan lahan adat kepada pengembang perumahan dengan harga tinggi. Harga tanah biasanya setara dengan nilai pasar terbuka tanah tersebut (Fiadzigbey, 2006; Ubink \& Quan, 2008).

Alasan lain perubahan penggunaan lahan untuk perumahan, para investor membangun rumah sewa di lahan pertanian untuk meningkatkan hasil lahan. Hal ini didukung oleh (Owusu-Ansah \& O'Connor, 2010) penduduk yang bekerja di perkotaan yang menginginkan tanah untuk perumahan, biasanya mencari alternatif rumah sewa dan tanah di pinggiran kota karena rendahnya harga tanah dan kebisingan di pinggiran. Masyarakat di pinggiran kota memberikan akses yang baik kepada warganya yang memungkinkan warganya untuk pulang pergi setiap hari ke tempat kerja mereka di pusat kota (Cobbinah \& Amoako, 2012).

\section{Dampak perubahan penggunaan lahan untuk pengembangan perumahan}

Perubahan penggunaan lahan diperlukan dan penting untuk pembangunan ekonomi dan kemajuan sosial. Namun tidak dipungkiri, dibalik keunggulannya tersebut menimbulkan masalah-masalah yang menyebabkan rusaknya kelestarian lingkungan, terganggunya keseimbangan ekologis, tercemarnya air, dan banjir. Setiap hujan dengan intesitas sedang hingga deras beberapa kawasan permukiman di Kota Padang mengalami banjir. Kejadian banjir itu sudah banyak diberitakan di media massa, mulai dari media lokal sampai kepada media nasional. Harian Padang Ekspres (Padeks), sebuah koran terkemuka di Sumatera Barat, hampir selalu memberitakan apabila terjadi bencana banjir tersebut. "Hujan lebat membuat sejumlah kawasan seperti Siteba, Alai, Mata Aia, Jondul Rawang, Sungai Sapih dan lainnya digenangi air", demikian Padeks memberitakan (Padang Ekspres, 2020). "Banjir melanda ratusan rumah di Kelurahan Sungai Sapih, Kota Padang, Sumatera Barat, Senin 1 Agustus 2016. Banjir terjadi setelah hujan deras melanda daerah itu sejak pagi ini" demikian media Republika menulis pada lamannya (Badan Pusat Statistik, 2020).

Banjir pada beberapa kawasan permukiman di Kota Padang sudah menjadi fenomena yang menjadi kegelisahan masyarakat dalam waktu yang lama. Sebagai sebuah fenomena, bajir itu dialami oleh banyak orang yang merupakan penduduk yang bertempat-tinggal di kawasan-kawasan perumahan tersebut. Tidak saja merugikan penduduk setempat, banjir juga menimbulkan dampak bagi masyarakat sekitar atau masyarakat yang secara fungsional berhubungan dengan kawasan tersebut. Sebagai sebuah kegelisahan, banjir itu terkesan belum ditangani secara tepat dan cepat. Penanganan banjir itu terlihat masih bersifat insidentil berupa tindakan tanggap darurat, seperti mengevakuasi warga, memberikan bantuan materil, dan penangananpenanganan yang tidak sampai kepada akar masalahnya. Kemudian, kejadian-kejadian banjir itu sudah berlangsung sejak lama, bahkan ada yang sejak perumahan itu baru ditempati oleh penghuninya dari semula.

Apabila dilihat dari sumbernya, sebagaimana juga peristiwa banjir di tempat lain, banjir yang terjadi di kawasan permukiman di Kota Padang dapat berasal dari salah satu atau gabungan dari dua sumber. Pertama, banjir terjadi akibat tidak tersalurkannya air hujan yang turun pada permukaan tanah suatu kawasan sehingga membuat genangan yang melebihi toleransi normal (Sebastian, 2008). Penyaluran air hujan yang turun ke permukaan tanah dapat berupa peresapan ke dalam tanah dan juga pengaliran melalui saluran pengeringan (drainase). Kedua, bajir terjadi akibat limpasan atau luapan dari saluran air baik kecil atau besar, berupa sungai, sehingga menggenangi permukaan tanah sekitar limpasan (Nugroho, 2008). Kawasan perumahan di Kota Padang yang mengalami banjir ada yang disebabkan oleh sumber pertama saja, atau sumber kedua saja, dan ada juga yang disebabkan oleh gabungan kedua sumber banjir di atas.

Kawasan perumahan dibangun di atas tanah yang dialif-fungsikan. Semula kawasan tersebut bisa berupa tanah kering berupa hutan, tanah hamparan, perkebunan, ladang dan sebagainya. Kawasan perumahan banyak juga yang sebelumnya merupakan lahan basah berupa sawah, tegalan dan lainnya. Di Kota Padang bahkan ada kawasan perumahan yang sebelumnya merupakan tanah tumbuh, yaitu tanah yang semula merupakan aliran sungai kemudian mengering baik oleh faktor alami atau buatan. Tanah tumbuh yang bersifat alami terjadi akibat pergeseran alur aliran sungai secara alamiah. Sedangkan tanah tumbuh yang bersifat buatan terjadi akibat adanya kegiatan proyek penataan alur aliran sungai secara sengaja, seperti normalisasi beberapa sungai di Kota Padang.

Banjir pada kawasan perumahan di Kota Padang disebabkan oleh alih fungsi lahan yang tidak tepat. Kawasan perumahan di daerah Air Pacah, Kecamatan Koto Tangah, yang langganan banjir dahulunya berupa daerah rendah dengan resapan yang rendah. Kawasan perumahan di daerah Tabing Banda Gadang, Kecamatan Nanggalo, dahulunya merupakan daerah alur aliran sungai kemudian mengering seiring adanya proyek normalisasi. Kawasan perumahan di daerah Sungai Sapih, Kecamatan Kuranji, sebelum kawasan perumahan didirikan, merupakan daerah rendah yang digunakan untuk bersawah oleh masyarakat. Disamping untuk lahan persawahan, lahan itu juga sejak dahulu sudah menjadi area limpasan air dari alur aliran sungai Banda Gadang Lolo Kasiak. 
Peran hukum administrasi perubahan penggunaan lahan untuk pengembangan perumahan

Peraturan Presiden Republik Indonesia Nomor 59 Tahun 2019 tentang Pengendalian Alih Fungsi Lahan Sawah. Pepres ini lahir didasari oleh luas alih fungsi lahan pangan khususnya sawah menjadi nonsawah semakin meningkat dengan pesat dari tahun ke tahun sehingga berpotensi dapat mempengaruhi produksi padi nasional. Pengendalian alih fungsi lahan sawah merupakan salah satu strategi peningkatan kapasitas produksi padi dalam negeri, sehingga perlu dilakuakn percepatan penetapan peta lahan sawah yang dilindungi dan pengendalian alih fungsi lahan sawah sebagai program nasional.

Berbeda dengan Provinsi Sumetera Barat telah melahirkan Perda no 16 Tahun 2008 tentang Tanah Ulayat dan Pemanfaatannya, yang jelas merupakan suatu pengejawantahan atas pengakuan pemerintah atas hukum adat sebagai suatu kesatuan masyarakat hukum dalam provinsi Sumatera Barat. Perda ini lahir didasari oleh tanah di Minangkabau tidaklah bersifat individual, melainkan milik komunal yaitu milik suku, kaum dan nagari.

Berdasarkan Peraturan Daerah Sumatera Barat proses pewarisan tanah itu, adalah didasarkan atas sistem kemasyarakatan yang berpolakan matrilineal (garis keturunan ibu) yaitu dari mamak kepada kemenakan. Dengan adanya pemilikan tanah tersebut maka seseorang dapat melakukan penguasaan atas tanah tersebut (Anwar, 1997). Garis keturunan ibu di Minangkabau erat kaitannya dengan sistem kewarisan pusako dan sako. Seandainya garis keturunan mengalami perubahan maka akan terjadi suatu perubahan dari sendi-sendi adat Minangkabau sendiri. Oleh karena itu bagi orang Minangkabau garis keturunan bukan hanya sekedar menentukan garis keturunan garis keturunan anak-anaknya melainkan dengan adatnya (Anwar, 1997).

Untuk itu, peran hukum administrasi terhadap penggunaan lahan tidak dapat diterapkan di daerah Minangkabau, ada dua hal yang memicu konflik tanah ulayat, yaitu: pertama, secara yuridis tanah ulayat merupakan tanah yang dikuasai oleh masyarakat adat tanpa alat bukti kepemilikkan karena sifatnya komunal. Konflik bermula ketika banyak pihak yang melakukan klaim atas tanah-tanah ulayat yang ada. Kedua, secara faktual telah terjadi proses sertifikasi terhadap tanah-tanah ulayat yang bertujuan umtuk memberikan jaminan kepastian hukum. Pada sisi lain proses ini menimbulkan konflik karena banyaknya pihak yang menolak sertifikasi atas tanah ulayat tersebut.

Tanah di Minangkabau merupakan suatu identitas diri karena tanah disini berfungsi sebagai pengikat hubungan baik antara suku maupun kaum sekaligus sebagai bukti asal usul. Dengan adanya tanah sebagai pengikat hubungan antar suku, kaum, maka akan terciptanya suatu interaksi sosial yang memperlihatkan akan kuatya eksistensi masyarakat Minangkabau itu sendiri. Dikarenakan tanah merupakan benda yang sangat berharga di tengah-tengah kehidupan masyarakat, sehingga banyak masyarakat yang menjadikan tanah sebagai harta warisan, yang dalam Minangkabau disebut juga sebagai harta pusaka. Harta Pusaka dimiliki oleh setiap kaum dalam suatu suku, dan telah diwariskan melalui beberapa generasi, sehingga harta ini tidak boleh diperjual-belikan kecuali dipegang atau gadaikan (Anwar, 1997). Transaksi ini baru dibolehkan setelah melalui rapat kaum yang dipimpin oleh penghulu dengan didasarkan atas beberapa pertimbangan, seperti "rumah gadang katirisan, gadih gadang indak balaki, mayik tabujua ditangah rumah, mambangkik batang tarandam" (Anwar, 1997).

\section{Simpulan}

Selama tidak adanya kesepakatan antar anggota kaum, maka tidak diperbolehkan transaksi tanah untuk pengembangan perumahan. Hal ini didasarkan atas sistem kemasyarakatan yang berpolakan matrilineal (garis keturunan ibu) yaitu dari mamak kepada kemenakan. Namun, keadaan ekonomi masyarakat sangat berpengaruh terhadap keputusan masyarakat untuk menjual lahannya. Transaksi ini baru dibolehkan setelah melalui rapat kaum yang dipimpin oleh penghulu dengan didasarkan atas beberapa pertimbangan, seperti "rumah gadang katirisan, gadih gadang indak balaki, mayik tabujua ditangah rumah, mambangkik batang tarandam". Penyalagunaan lahan untuk pengembangan perumahan akan berdampak pada hilangnya area resapan air hujan yang menyebabkan rusaknya kelestarian lingkungan, terganggunya keseimbangan ekologis, tercemarnya air, dan banjir. Setiap hujan dengan intesitas sedang hingga deras beberapa kawasan permukiman di Kota Padang mengalami banjir, sejumlah kawasan seperti Siteba, Alai, Mata Aia, Jondul Rawang, Sungai Sapih dan lainnya.

\section{Referensi}

Agheyisi, J. E. (2019). Inter-communal Land Conflicts in Benin City, Nigeria: Exploring the Root Causes in the Context of Customary Land Supply. Land Use Policy, 83, 532-542.

Akbar, S. (2010). Penyelesaian Sengketa Tanah Hak Ulayat Dalam Suku Caniago Di Nagari Muara Panas Kabupaten 
Solok Provinsi Sumatera Barat. (Doctoral dissertation, Universitas Diponegoro).

Anwar, C. (1997). Hukum Adat Indonesia : Meninjau Hukum Adat Minangkabau. Jakarta: Rhineka Cipta.

Badan Pusat Statistik. (2020). Kota Padang, Kota Padang Dalam Angka - Penyediaan Data Untuk Perencanaan Pembangunan.

Barry, M., \& Danso, E. K. (2014). Tenure Security, Land Registration and Customary Tenure in a Peri-urban Accra Community. Land Use Policy, 39, 358-365.

Berry, S. (2009). 'Property, Authority and Citizenship: Land Claims, Politics and the Dynamics of Social Division in West Africa. Development and Change, 40(1), 23-45.

Bintarto. (1984). Urbanisasi dan Permasalahannya. Jakarta: Ghalia Indonesia.

Boone, C. (2017). Sons of the Soil Conflict in Africa: Institutional Determinants of Ethnic Conflict Over Land. World Development, 96, 276-293.

Cobbinah, P. B., \& Amoako, C. (2012). Urban Sprawl and the Loss of Peri-Urban Land in Kumasi, Ghana. International Journal of Social and Human Sciences, 6, 388-397.

Dewi, N. K., \& Rudiarto, I. (2013). Identifikasi Alih Fungsi Lahan Pertanian dan Kondisi Sosial Ekonomi Masyarakat Daerah Pinggiran di Kecamatan Gunungpati Kota Semarang. Wilayah Dan Lingkungan, 1(2), 175-188.

Fiadzigbey, M. E. (2006). Customary Land Administrator in Ghana - Challenges and Prospects Customary Land Administrator in Ghana - Challenges and Prospects. In XXIII FIG Congress, Munich, Germany, October, $8-13$.

Fosu, A. (2021). Housing Development, Local Land Conflicts and Sustainable Land-use Planning in Periurban Ghana. African Journal on Land Policy and Geospatial Sciences, 4(1), 116-132.

Jauhari, A., \& Ritohardoyo, S. (2013). Dampak Pembangunan Perumahan Terhadap Perubahan Penggunaan Lahandan Kondisi Sosial-Ekonomi Penjual Lahan di Kecamatan Mlati. Jurnal Bumi Indonesia, 2(2), 192 201.

Kalabamu, F. T. (2019). Land Tenure Reforms and Persistence of Land Conflicts in Sub-Saharan Africa - The Case of Botswana. Land Use Policy, 81, 337-345.

Kleemann, J., Inkoom, J. N., Thiel, M., Shankar, S., Lautenbach, S., \& Fürst, C. (2017). Peri-urban Land Use Pattern and Its Relation to Land Use Planning in Ghana, West Africa. Landscape and Urban Planning, 165, 280-294.

Knox, A., \& Jones-Casey, K. (2011). Farmer-herder conflicts in Mali.

Kuusaana, E. D., Bukari, K. N., Danyi, E., \& Bukari, K. N. (2015). Land Conflicts between Smallholders and Fulani pastoralists in Ghana : Evidence from the Asante Akim North District ( AAND ). Journal of Rural Studies, 42, 52-62.

Mwesigye, F., \& Matsumoto, T. (2016). The Effect of Population Pressure and Internal Migration on Land Conflicts : Implications for Agricultural Productivity in Uganda. World Development, 79, 25-39.

Nugroho, S. P. (2008). Analisis Curah Hujan Penyebab Banjir Besar di Jakarta pada Awal Februari 2007. Jurnal Air Indonesia, 4(1).

Owusu-Ansah, J. K., \& O'Connor, K. B. (2010). Housing Demand in the Urban Fringe Around Kumasi, Ghana. Journal of Housing and the Built Environment, 25, 1-17.

Sebastian, L. (2008). Pendekatan Pencegahan dan Penanggulangan Banjir.

Siiba, A., Adams, E. A., \& Cobbinah, P. B. (2018). Chieftaincy and Sustainable Urban Land Use Planning in Yendi, Ghana: Towards Congruence. Cities, 73, 96-105.

Sitorus, S. R. (2018). Perencanaan Penggunaan Lahan. Peneribit IPB Press.

Syaodih, N. (2009). Metode Penelitian Pendidikan. Bandung: Remaja Rosdakarya.

Ubink, J. M., \& Quan, J. F. (2008). How to Combine Tradition and Modernity ? Regulating Customary Land Management in Ghana. Land Use Policy, 25, 198-213.

Wahyu, R. K., Haryani, H., \& Nori, Y. (2020). Kajian Perubahan Pengunaan Lahan Serta Faktor-Faktor Yang Mendorong Perubahan Pengunaan Lahan di Kecamatan Kuranji Kota Padang. (Doctoral dissertation, Universitas Bung Hatta). 